\title{
PENCEGAHAN STUNTING DI MEDOKAN SEMAMPIR SURABAYA MELALUI MODIFIKASI MAKANAN PADA ANAK
}

Idham Choliq ${ }^{1}$, Dede Nasrullah ${ }^{2}$, Mundakir ${ }^{3}$

Fakultas Ilmu Kesehatan, Universitas Muhammadyah Surabaya

Idhamcholiq96@gmail.com¹, dedenasrullah@um-surabaya.ac.id² mundakirzhafran@gmail.com³

Submited : Januari 2020 Acepted : Maret 2020 Published : April 2020

\begin{abstract}
Abstrak
Stunting merupakan permasalahan yang semakin banyak ditemukan di negara berkembang, termasuk Indonesia. Prevalensi balita pendek mengalami peningkatan dari tahun 2016 yaitu 27,5\% menjadi 29,6\% pada tahun 2017 (Kemenkes, 2018). Pada tahun 2015, hasil Pemantauan Status Gizi (PSG) prevalensi stunting di Jawa Timur 27,1\% dan di Surabaya adalah 20,3\% (Kementerian Kesehatan RI, 2016). Kelurahan Medokan Semampir Sebagai wilayah mitra program ini merupakan salah satu wilayah kerja Puskesmas Keputih Surabaya. Di sana stunting masih menjadi masalah serius. Berbasarkan data di 2017 prevalensi stunting sebesar 30,48\% di Kelurahan Medokan Semampir. Salah satu faktor yang berpengaruh pada kejadian stunting adalah makanan pengganti asi (MP-ASI) yang kurang tepat dan sehat. Pola makan ibu dapat berkontribusi dalam meningkatkan angka kejadian stunring. Ibu memiliki tanggung jawab utama untuk memilih, menyiapkan, dan menyajikan makanan bergizi untuk anak-anak mereka. Pemberdayaan masyarakat ini dilakukan sebagai upaya penyelesaian masalah gizi anak stunting. Luaran yang diharapkan melalui program ini adalah modul pembuatan menu modifikasi makanan sehat, produk makanan dan meningkatkan status kesehatan keluarga terutama anak. Dengan upaya perbaikan gizi berbasis modifikasi makanan pengganti asi (MP-ASI) yang ekonomis serta menarik yang memiliki manfaat meningkatkan status kesehatan anak diharapkan angka stunting dapat dikurangi dan masyarakat juga bisa memperoleh keuntungan dari program tersebut.
\end{abstract}

Kata Kunci : : Makanan, Pemberdayaan, Stunting 


\section{PENDAHULUAN}

Stunting merupakan permasalahan yang semakin banyak ditemukan di negara berkembang, termasuk Indonesia. Menurut United Nations International Children's Emergency Fund (UNICEF) satu dari tiga anak mengalami stunting. Sekitar $40 \%$ anak di daerah pedesaan mengalami pertumbuhan yang terhambat (Hasandi, Maryanto, \& Anugrah, 2019). Konsekuensi stunting dapat bersifat jangka pendek dan jangka panjang, termasuk peningkatan morbiditas dan mortalitas, perkembangan anak yang buruk dan mempengaruh kemampuan belajar, peningkatan risiko infeksi dan penyakit tidak menular di masa dewasa, dan berkurangnya produktivitas (Beal, et. al, 2018).

Berdasarkan data World Health Organization (WHO), Indonesia termasuk ke dalam negara ketiga dengan prevalensi tertinggi di regional Asia Tenggara/South-East Asia Regional (SEAR). Rata-rata prevalensi balita stunting di Indonesia tahun 2005-2017 adalah 36,4\% (Kemenkes, 2018). Berdasarkan data Pemantauan Status Gizi (PSG) selama tiga tahun terakhir, pendek memiliki prevalensi tertinggi dibandingkan dengan masalah gizi lainnya seperti gizi kurang, kurus, dan gemuk. Prevalensi balita pendek mengalami peningkatan dari tahun 2016 yaitu 27,5\% menjadi 29,6\% pada tahun 2017 (Kemenkes, 2018). Pada tahun 2015, hasil Pemantauan Status Gizi (PSG) prevalensi stunting di Jawa Timur 27,1\% dan di Surabaya adalah 20,3\% (Kementerian Kesehatan RI, 2016).

Kelurahan Medokan Semampir Sebagai wilayah mitra program iini merupakan salah satu wilayah kerja Puskesmas Keputih Surabaya. Di sana stunting masih menjadi masalah serius. Berbasarkan data di 2017 prevalensi stunting sebesar 30,48\% di Kelurahan Medokan Semampir. Salah satu factor yang berpengaruh pada kejadian stunting adalah makanan pengganti asi (MP-ASI) yang kurang tepat dan sehat (Widyastuty, 2018).

Salah satu faktor terpenting untuk meningkatnya angka stunting anak mungkin adalah pola makan ibu. Ibu memiliki tanggung jawab utama untuk memilih, menyiapkan, dan menyajikan makanan bergizi untuk anak-anak mereka (Hasan et al., 2019). Selain pola makan dari ibu, penyakit infeksi juga merupakan faktor penyebab terjadinya stunting (Hasandi et al., 2019)

Pemberian makanan tinggi zinc sangat tepat untuk diberikan kepada anak balita. Nutrisi zinc penting untuk kesehatan manusia khususnya balita karena zinc terlibat dalam berbagai proses metabolisme sebagai katalis, ion pengatur atau elemen struktural protein (Hinnouho et al., 2019). Namun, tantangannya adalah bagaimana menyuguhkan makanan tinggi zinc tersebut dalam bentuk kudapan sehingga dapat menarik untuk dimakan.

Pemberdayaan masyarakat ini dilakukan sebagai upaya penyelesaian masalah gizi anak stunting. Luaran yang diharapkan melalui program ini adalah modul pembuatan menu modifikasi makanan sehat, produk makanan dan meningkatkan status kesehatan keluarga terutama anak. Dengan upaya perbaikan gizi berbasis modifikasi makanan pengganti asi (MP-ASI) yang ekonomis serta menarik yang memiliki manfaat meningkatkan status keshatan anak diharapkan angka stunting dapat dikurangi dan masyarakat juga bias memperoleh keuntungan dari program tersebut. 


\section{TINJAUAN PUSTAKA}

\section{Pengertian Stunting}

Stunting merupakan kondisi dimana balita dinyatakan memiliki panjang atau tinggi yang pendek dibanding dengan umur. Panjang atau tinggi badannya lebih kecil dari standar pertumbuhan anak dari WHO (Kemenkes, 2018). Stunting adalah kondisi gagal tumbuh pada anak balita akibat kekurangan gizi kronis sehingga anak lebih pendek untuk usianya. Kekurangan gizi terjadi sejak bayi dalam kandungan dan pada masa awal kehidupan setelah lahir, tetapi baru tampak setelah anak bersusia 2 tahun (Izwardy, 2019).

Stunting adalah anak balita (bayi di bawah lima tahun) yang gagal tumbuh akibat dari kekurangan gizi kronis sehingga anak terlalu pendek untuk usianya. Kekurangan gizi terjadi sejak bayi dalam kandungan dan pada masa awal setelah bayi lahir akan tetapi, kondisi stunting baru nampak setelah bayi berusia 2 tahun. Balita pendek (stunted) dan sangat pendek (severely stunted) adalah balita dengan panjang badan $(\mathrm{PB} / \mathrm{U})$ atau tinggi badan $(\mathrm{TB} / \mathrm{U})$ menurut umurnya dibandingkan dengan standar baku WHO-MGRS (Multicentre Growth Reference Study) 2006. Sedangkan definisi stunting menurut Kementerian Kesehatan (Kemenkes) adalah anak balita dengan nilai z-scorenya kurang dari -2SD/standar deviasi (stunted) dan kurang dari - 3SD (severely stunted) (Tim Nasional Percepatan Penanggulangan Kemiskinan, 2017)

\section{Penyebab Stunting}

Stunting disebabkan oleh faktor multi dimensi dan tidak hanya disebabkan oleh faktor gizi buruk yang dialami oleh ibu hamil maupun anak balita. Intervensi yang paling menentukan untuk dapat mengurangi pervalensi stunting oleh karenanya perlu dilakukan pada 1.000 Hari Pertama Kehidupan (HPK) dari anak balita. Secara lebih detil, beberapa faktor yang menjadi penyebab stunting dapat digambarkan sebagai berikut (Kemenkes, 2018):

1. Praktek pengasuhan yang kurang baik

2. Masih terbatasnya layanan kesehatan termasuk layanan ANC-Ante Natal Care (pelayanan kesehatan untuk ibu selama masa kehamilan) Post Natal Care dan pembelajaran dini yang berkualitas)

3. Masih kurangnya akses rumah tangga/ keluarga ke makanan bergizi.

4. Kurangnya akses ke air bersih dan sanitasi

\section{Dampak Stunting}

Dampak yang ditimbulkan stunting dapat dibagi menjadi dampak jangka pendek dan jangka panjang (Tim Nasional Percepatan Penanggulangan Kemiskinan, 2017)

1. Dampak Jangka Pendek.

a. Peningkatan kejadian kesakitan dan kematian

b. Perkembangan kognitif, motorik, dan verbal pada anak tidak optimal

c. Peningkatan biaya kesehatan.

2. Dampak Jangka Panjang.

a. Postur tubuh yang tidak optimal saat dewasa (lebih pendek dibandingkan pada umumnya);

b. Meningkatnya risiko obesitas dan penyakit lainnya;

c. Menurunnya kesehatan reproduksi; d. Kapasitas belajar dan performa yang kurang optimal saat masa sekolah; dan

d. Produktivitas dan kapasitas kerja yang tidak optimal. 


\section{Intervensi Stunting di Indonesia}

Kerangka intervensi stunting di Indonesia terbagi menjad dua, yaitu Intervensi Gizi Spesifik dan Intervensi Gizi Sensitif (Tim Nasional Percepatan Penanggulangan Kemiskinan, 2017)

1. Intervensi Gizi Spesifik

$$
\text { Intervensi yang ditujukan }
$$

kepada anak dalam 1.000 Hari Pertama Kehidupan (HPK) dan berkontribusi pada $30 \%$ penurunan stunting. Intervensi ini digunakan di bidang kesehatan dan bersifat jangka pendeka, hasil dicatat dalam waktu relative pendek. Intervensi Gizi Spesifik dapat menjadi beberapa intervensi utama yang dimulai dari masa kehamilan ibu hingga melahirkan balita

1) Intervensi Gizi Spesifik dengan sasaran Ibu Hamil

2) Intervensi Gizi Spesifik dengan sasaran Ibu Menyusui dan Anak Usia 0-6 Bulan.

3) Intervensi Gizi Spesifik dengan sasaran Ibu Menyusui dan Anak Usia 7-23 bulan.

\section{Intervensi Gizi Sensitif}

Intervensi ini dilakukan melalui berbagai kegiatan di luar sekor kesehatan dan berkontribusi pada 70\% intervensi stuting. Sasaran dari intervensi gizi spesifik adalah masyarakat secara umum dan tidak khusus ibu hamil dan balita pada 1.000 Hari Pertama Kehidupan/HPK. Kegiatan terkait Intervensi Gizi Sensitif dapat dilaksanakan melalui beberapa kegiatan yang umumnya makro dan dilakukan secara lintas Kementerian dan Lembaga. Ada 12 kegiatan yang dapat berkontribusi pada penurunan stunting melalui
Intervensi Gizi Spesifik sebagai berikut:

1. Menyediakan dan memastikan akses terhadap air bersih.

2. Menyediakan dan memastikan akses terhadap sanitasi.

3. Melakukan fortifikasi bahan pangan.

4. Menyediakan akses kepada layanan kesehatan dan Keluarga Berencana (KB).

5. Menyediakan Jaminan Kesehatan Nasional (JKN)

6. Menyediakan Jaminan Persalinan Universal (Jampersal).

7. Memberikan pendidikan pengasuhan pada orang tua.

8. Memberikan Pendidikan Anak Usia Dini (PAUD) Universal.

9. Memberikan pendidikan gizi masyarakat.

10. Memberikan edukasi kesehatan seksual dan reproduksi, serta gizi pada remaja.

11. Menyediakan bantuan dan jaminan sosial bagi keluarga miskin.

12. Meningkatkan ketahanan pangan dan gizi

\section{Pengukuran Status Gizi}

a. Status gizi balita dinilai menurut 3 indeks, yaitu Berat Badan Menurut Umur (BB/U), Tinggi Badan Menurut Umur (TB/U), Berat Badan Menurut Tinggi Badan (BB/ TB).

1) $\mathrm{BB} / \mathrm{U}$ adalah berat badan anak yang dicapai pada umur tertentu.

2) $T B / U$ adalah tinggi badan anak yang dicapai pada umur tertentu.

3) $\mathrm{BB} / \mathrm{TB}$ adalah berat badan anak dibandingkan dengan tinggi badan yang dicapai. 
Ketiga nilai indeks status gizi diatas dibandingkan dengan baku pertumbuhan WHO

b. Z-score adalah nilai simpangan $\mathrm{BB}$ atau TB dari nilai $\mathrm{BB}$ atau TB normal menurut baku pertumbuhan WHO.
Batasan untuk kategori status gizi balita menurut indeks BB/U, TB/U, BB/TB menurut WHO dapat dilihat pada tabel "pengertian kategori status gizi balita" (Kementerian Kesehatan RI, 2018)

c. Contoh perhitungan $\mathrm{Z}$ score $\mathrm{BB} / \mathrm{U}$ : (BB anak - BB standar)/standar deviasi BB standar

\begin{tabular}{|c|c|c|}
\hline Indikator & Status Gizi & Z-Score \\
\hline \multirow{4}{*}{$\mathrm{BB} / \mathrm{U}$} & Gizi Buruk & $<-3,0$ SD \\
\hline & Gizi Kurang & $-3,0 \mathrm{SD} s / \mathrm{d}<-2,0 \mathrm{SD}$ \\
\hline & Gizi Baik & $-2,0 \mathrm{SD} s / \mathrm{d} 2,0 \mathrm{SD}$ \\
\hline & Gizi Lebih & $>2,0 \mathrm{SD}$ \\
\hline \multirow{3}{*}{ TB/U } & Sangat Pendek & $<-3,0$ SD \\
\hline & Pendek & $-3,0 \mathrm{SD} s / \mathrm{d}<-2,0 \mathrm{SD}$ \\
\hline & Normal & $\geq-2,0 \mathrm{SD}$ \\
\hline \multirow{4}{*}{ BB/TB } & Sangat Kurus & $<-3,0$ SD \\
\hline & Kurus & $-3,0 \mathrm{SD} s / \mathrm{d}<-2,0 \mathrm{SD}$ \\
\hline & Normal & $-2,0 \mathrm{SD} s / \mathrm{d} 2,0 \mathrm{SD}$ \\
\hline & Gemuk & $>2,0 \mathrm{SD}$ \\
\hline
\end{tabular}

Pengertian istilah

1. Underweight/Berat badaan kurang/Gizi Kurang: Gabungan gizi buruk dan gizi kurang

2. Stunting/Pendek: Gabungan sangat pendek dan pendek

3. Wasting/kurus: gabungan sangat kurus dan kurus 


\section{METODE PENELITIAN}

Ada beberapa tahapan yang dilakukan dalam program pengabdian masyarakat mulai dari persiapan program sampai pada tahap pelaksaan program di antara

\section{Metode Pendekatan}

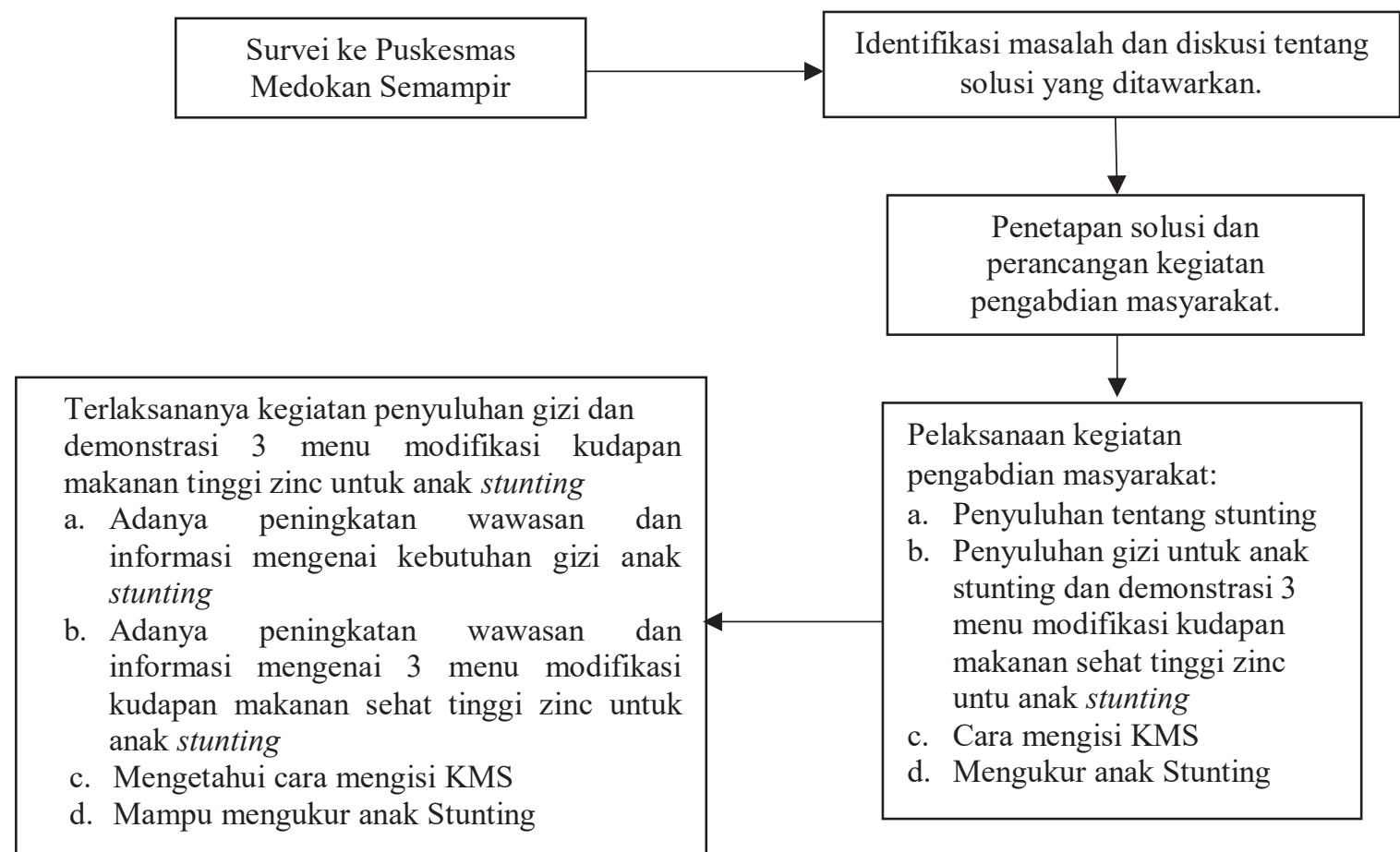

\section{Survei ke Puskesmas Medokan Semampir}

Kunjungan peneliti ke Puskesmas Medokan Semampir adalah untuk bertemu dengan Kepala Puskesmas, Ahli Gizi dan Kader di daerah Medokan Semampir untuk menyampaikan maksud kunjungan. Pada tahap ini, peneliti juga sekaligus mengidentifikasi masalah yang dihadapi oleh mitra. Mitra menerima kunjungan dan diskusi mengenai kendala masyarakat terhadap masalah stunting. Berdasarkan keterangan kader, masyarakat masih belum sadar tentang kesehatan gizi dan cara pencegahan stunting.

\section{Identifikasi masalah dan solusi yang ditawarkan.}

Identifikasi masalah didapatkan setelah melakukan diskusi dengan Kepala

Puskesmas, ahli gizi dan kader di Wilayah kerja Puskesmas Medokan Semampir dan mencari alternatif solusi.

1. Penetapan solusi dan perancangan

kegiatan pengabdian masyarakat.

Solusi yang dipilih berdasarkan pada masalah yang dihadapi dan prinsip evindence-based practice. Melibatkan Kepala Puskesmas, ahli gizi dan kader mengenai solusi yang diambil Penetapan. Melibatkan anak stunting dalam kegiatan

2. Pelaksanaan kegiatan pengabdian masyarakat:

a. Memberikan penyuluhan tentang stunting: pengertian, penyebab, dampak dan intervensi yang harus dilakukan.

b. Penyuluhan gizi untuk anak stunting 
dan demonstrasi 3 menu modifikasi kudapan makanan sehat tinggi zinc untuk anak stunting oleh Ahli Gizi

c. Praktek pengisian Kartu Menuju Sehat (KMS) agar ibu dapat mengisi secara mandiri di rumah

d. Praktek pengukuran anak Stunting

3. Evaluasi Pelaksanaan dan Keberlanjutan Program

Langkah evaluasi pelaksanaan program dan keberlanjutan program di lapangan setelah kegiatan pengabdian masyarakat selesai dilaksanakan adalah:

a. Follow Up via Short Mesanger Service (SMS) selama satu bulan untuk memantau makanan yang dikonsumsi anak setiap hari.

b. Mengevaluasi perkembangan status gizi anak stunting yang dilihat dari grafik berat badan pada Kartu Menuju Sehat (KMS) dan diharapkan tidak terjadi penurunan grafik berat badan di Bawah garis Merah (BGM).

\section{HASIL DAN PEMBAHASAN}

\section{Profil Mitra}

Kelurahan Medokan Semampir Sebagai wilayah mitra program ini merupakan salah satu wilayah kerja Puskesmas Keputih Surabaya. Di sana stunting masih menjadi masalah serius. Berbasarkan data di 2017 prevalensi stunting sebesar 30,48\% di Kelurahan Medokan Semampir. Salah satu faktor yang berpengaruh pada kejadian stunting adalah makanan pengganti asi (MP-ASI) yang kurang tepat dan sehat.

\section{Gambaran Umum Kegiatan}

Kegiatan pengabdian masyarakat ini merupakan bentuk solusi yang ditawarkan terhadap isu Stunting di Kelurahan Medokan Semampir dengan sasaran para Ibu dengan anak stunting. Kegiatan pengabdian masyarakat ini memiliki tujuan untuk mengatasi masalah gizi yang dialami oleh anak Kelurahan Medokan Semampir, Surabaya yang berpengaruh pada peningkatan derajat kesehatan gizi anak. Bentuk kegiatannya penyuluhan gizi, demonstrasi 3 menu modifikasi kudapan makanan sehat tinggi zinc untu anak stunting, pengisian KMS dan pengukuran anak Stunring. Kegiatan ini dilakukan selama 1 bulan, mulai 5 Agustus- 5 September 2019.

\section{Pelaksanaan Mekanisme dan Rancangan}

Pada minggu pertama, kami melakukan kordinasi dengan pihak kader dan ibu untuk mementukan hari yang pas, dan menyiapkan bahan-bahan yang diperlukan untuk demonstrasi memasak kudapan makanan bergizi untuk anak stunting. Minggu kedua merupakan kegiatan penyuluhan dan demonstrasi. Kegiatan dimulai dengan memberikan materi tentang stunting. Dijelaskan tentang pengertian stunting, penyebabnya, dampak kerusakan yang diakibatkan oleh stunting pada anak, dan intervensi untuk menangani kasus stunting. Selain itu, penyuluhan tentang gizi dan menu sehat untuk anak stunting. Lalu dilanjutkan dengan demontrasi memasak menu makanan sehat berupa siomay kerang, mash potato udang, dan empek-empek ikan mujair. Kader dan para ibu terlibat dalam proses demonstrasi. Sampai mereka benar-benar bisa praktek memasak sebagai skill mereka di rumah. Pada minggu ketiga, dilakukan praktek 
cara mengisi Kartu Menuju Sehat (KMS) dan pengukuran berat dan tinggi balita, dan menghitung apakah anak masih mengalami stunting. Di Minggu ke empat, dilakukan evaluasi tentang pemahaman kader dan ibu tentang stunting, cara memasak makanan sehat untuk stunting sesuai menu yang kami berikan. Cara pengisian KMS dan menghitung tinggi dan berat badan. Kemudian membahas tentang keberlanjutan program.

\section{Hasil Pelaksanaan Kegiatan dan Pembahasan}

Kegiatan penyuluhan dan demo memasak kudapan sehat untuk balita stunting dirasa sangat bermanfaat oleh peserta. Mereka baru sadar bahwa menjaga nutrisi selama kehamilan merupakan periode penting untuk mencegah terjadinya stunting. Mereka juga sebelumnya tidak pernah tahu tentang kandungan gizi yang harus diberikan kepada anaknya setelah periode pemberian ASI eksklusif. Mereka sangat antusias dalam mengikuti kegiatan demo memasak kudapan sehat. Mereka berpartisipasi secara aktif selama acara berlangsung.

Untuk hasil makanan yang dimasak telah disesuiakan dengan dengan mengganti bahanbahan dasar yang mempunyai kandungan zinc tinggi dan harganya terjangkau oleh masyarakat. Bahan-bahan tersebut meliputi siomay kerang, mash potato udang, dan empekempek ikan mujair. Berdasarkan beberapa penelitian diketahui bahwa konsumsi zinc berpengaruh terhadap antropometri balita pada masa pertumbuhan (Hinnouho et al., 2019).
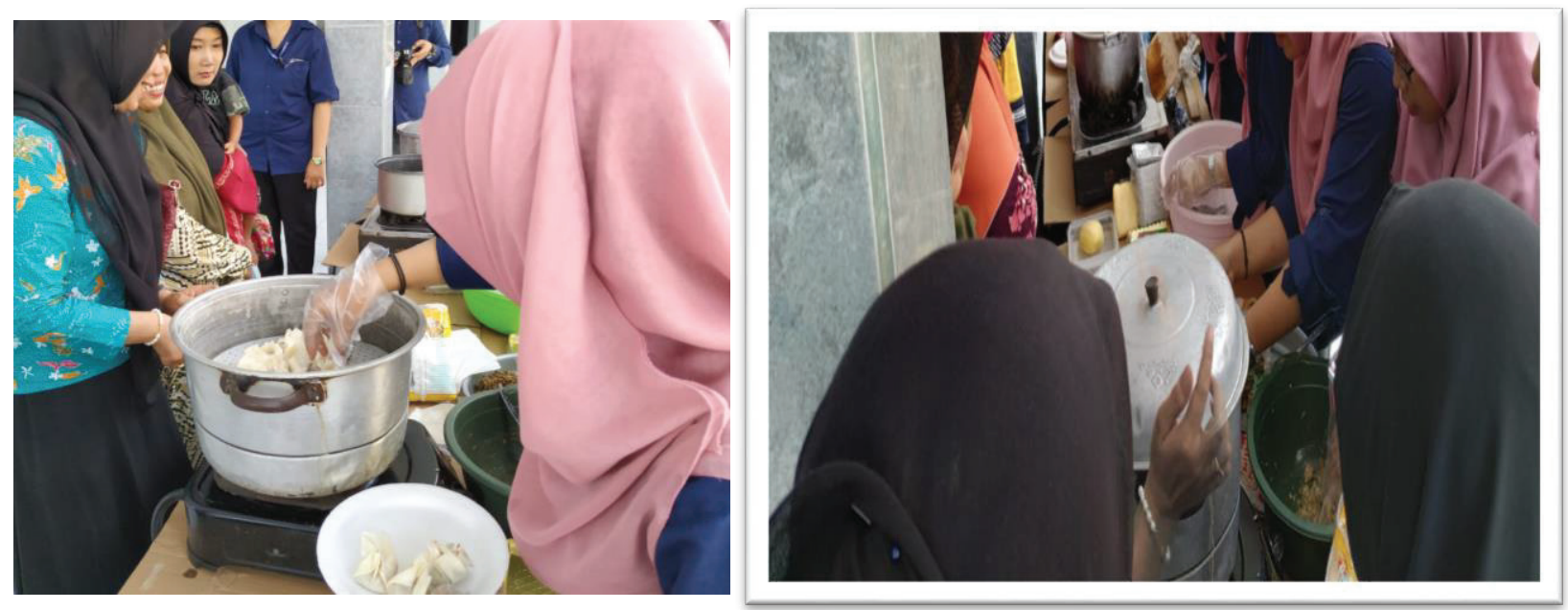

Gambar 4.1 Demontrasi memasak bersama kader dan peserta ibu-ibu
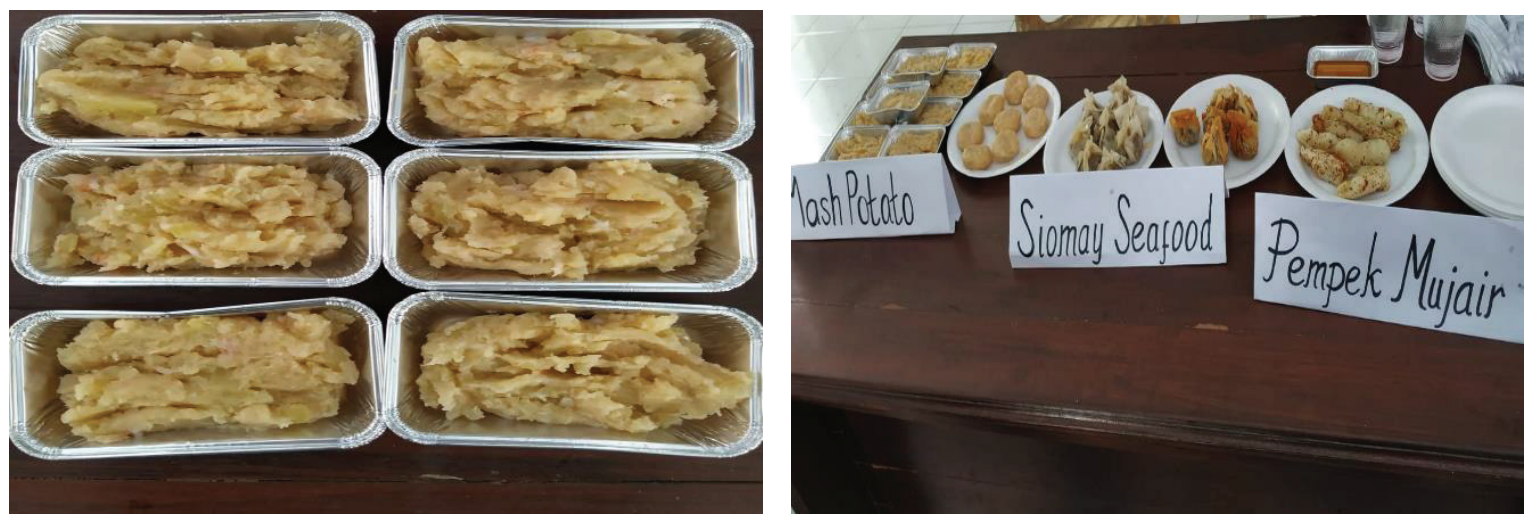

Gambar 4.2 hasil masakan 
Pada saat acara penyuluhan dan demo memasak, peserta yang merupakan ibu balita stunting, aktif bertanya dan ikut mencoba memasak menu kudapatan yang didemokan. Dengan diajarkan menu modifikasi kudapatan sehat untuk balita stunting diharapkan ibu balita lebih mengerti tentang menu kudapan yang mengandung gizi sehat untuk anaknya, terutama yang mengandung zinc tinggi yang berguna bagi pertumbuhan anak stunting. Mereka juga menunjukkan kemampuan dalam mengisi dan meneremahkan isi KMS dan kriteria anak dengan Stunting. Sebuah bukti keberhasilan dari program pengabdian ini.

\section{KESIMPULAN}

Kesimpulan dari program pengabdian yang berujudul "Modifikasi Makanan Dalam Upaya Menurunkan Angka Stunting di Medokan Semampir Surabaya" sebagai berikut:

1. Kader dan peserta memahami secara pengertian, penyebab, dampak dan intervensi untuk stunting.

2. Kaderdanpesertamampumendemonstrasikan 3 menu modifikasi kudapan makanan sehat tinggi zinc untuk anak stunting.

\section{Kader dan peserta mampu mengisi KMS}

4. Kader dan peserta mampu mengukur anak dan mengetahui kategori mana anak yang termasuk stunting.

\section{UCAPAN TERIMAKASIH}

Pengabdian ini tidak akan terlaksana dan berjalanan dengan lancer jika tidak ada bantuan dari beberapa pihak. Pada kesempatan ini, kami berterima kasih kepada: $\begin{array}{llr}\text { 1. Pimpinan } & \text { Fakutas ilmu } & \text { Kesehatan } \\ \text { Universitas } & \text { Muhammadiyah } & \text { Surabaya }\end{array}$ yang telah memberi kepercayaan kepada kami untuk melakukan pemberdayaan masyarakat.

2. Pihak Puskesmas Keputih dan pihak kelurahan medokan semampir yang menginjinkan kam untuk melakukan pemberdayaan di wilayah kerjanya.

3. Kader-kader ibu dan anak yang rela meluangkan waktunya untuk mengajak ibuibu untuk ikut berpartisipasi dalam kegiatan pengabdian ini.

4. Dan pihak-pihan lain yang secara langsung dan tidak lansung terlibat dalam pelakasaaan program ini

\section{DAFTAR PUSTKA}

Beal, T., Tumilowicz, A., Sutrisna, A., Izwardy, D., \& Neufeld, L. M. (2018). A review of child stunting determinants in Indonesia. Maternal and Child Nutrition, 14(4), 1-10. https://doi.org/10.1111/mcn.12617

Hasan, M., Islam, M. M., Mubarak, E., Haque, M. A., Choudhury, N., \& Ahmed, T. (2019). Mother's dietary diversity and association with stunting among children $<2$ years old in a low socio-economic environment: A case-control study in an urban care setting in Dhaka, Bangladesh. Maternal and Child Nutrition, 15(2), 1-8. https://doi.org/10.1111/mcn.12665

Hasandi, L. A., Maryanto, S., \& Anugrah, R. M. (2019). JGK-vol.11, no. 25 Januari 2019. 11(25), 29-38.

Hinnouho, G. M., Bernstein, R. M., Barffour, M. A., Arnold, C. D., Wessells, K. R., Ratsavong, K., ... Hess, S. Y. (2019). Impact of two forms of daily preventive zinc or therapeutic zinc supplementation for diarrhea on hair cortisol concentrations among rurallaotian children:Arandomized controlled trial. Nutrients, 11(1). https:// doi.org/10.3390/nu11010047

Kemenkes. (2018). Buletin Stunting. Kementerian Kesehatan Republik Indonesia, 301(5), 1163-1178. 
Kementerian Kesehatan RI. (2018). Buku saku pemantauan status gizi. Buku Saku Pemantauan Status Gizi Tahun 2017, 7-11.

Tim Nasional Percepatan Penanggulangan Kemiskinan. (2017). 100 KABUPATEN/ KOTAPRIORITASUNTUKINTERVENSI ANAK KERDIL (STUNTING). 